\title{
The Point Is to Change It! Introduction to Critical Political Interventions in Media and Communication Studies
}

\author{
Sašo Slaček Brlek; Jernej Amon Prodnik \\ Social Communication Research Centre, Faculty of Social Sciences, University of Ljubl- \\ jana, Slovenia, saso.brlek-slacek@fdv.uni-lj.si, jernej.amon-prodnik@fdv.uni-lj.si
}

\begin{abstract}
The intention of this paper is to provide a historical overview and an introduction to the interviews with Bodgan Osolnik, Breda Pavlič, Cees Hamelink, Daya K. Thussu, Peter Golding and Dan Hind presented in this special section. Following Marx, we entitled the section The Point Is to Change It! Critical Political Interventions in Media and Communication Studies. We discuss the need for critical theory to bridge the divide between theory and practice because this notion is central to all of the interviews in one way or another. We also provide a historical contextualization of important theoretical as well as political developments in the 1970s and 1980s. This period may be seen as a watershed era for the critical political economy of communication and for the political articulation of demands for a widespread transformation and democratization in the form of the New World Information and Communication Order initiative. We believe that many contemporary issues have a long history, with their roots firmly based in this era. The historical perspective therefore cannot be seen as nostalgia, but as an attempt to understand the historical relations of power and how they have changed and shifted. In our view, the historical perspective is crucial not only for understanding long-lasting historical trends, but also to remind ourselves that the world is malleable, and to keep alive the promises of the progressive struggles of the past.
\end{abstract}

Keywords: Praxis, Critical Political Economy of Communication, Karl Marx, MacBride Report, New World Information and Communication Order, UNESCO, New International Economic Order

Dedication: We dedicate this section to Jernej's daughter Zoja, born on the very evening we were finishing this manuscript. Whether she chose to emerge then because she was fed up with our endless ramblings about a bygone era or she felt inspired to enter the world in order to change it remains to be seen.

In his 11th thesis on Feuerbach, Marx penned one of his most quoted lines, famously claiming that "The philosophers have only interpreted the world in various ways; the point is to change it" (Marx 1975c, 5, emphasis in original). This quote has often been interpreted as an outright dismissal of philosophy, an activist call to arms, which must simultaneously bring an end to theoretical flights of fancy. Heidegger, for example, charged Marx with supposedly overlooking the fact that "changing the world presupposes a change in the conception of the world and that we can arrive at a conception of the world only by interpreting it adequately". ${ }^{1}$ Presumably, Marx wrote Capital simply out of boredom rather than to provide an adequate interpretation of the world as a basis for social change.

\footnotetext{
${ }^{1}$ See: www.youtube.com/watch?v=OxmzGT1w_kk (February 15, 2017).
} 
Yet, even a great thinker like Adorno seems to have succumbed to an interpretation that pits theory and practice against each other, choosing this bold statement to be the opening lines of Negative dialectics: "Philosophy, which once seemed obsolete, lives on because the moment to realize it was missed" (Adorno 1966/1973, 3). He further elaborates: "A practice indefinitely delayed is no longer the forum for appeals against self-satisfied speculation; it is mostly the pretext used by executive authorities to choke, as vain, whatever critical thoughts the practical change would require" (Ibid.). The problem with such a statement is not merely that the wholesale retreat from practice is too pessimistic - after all, the charge of pessimism is a purely subjective one, and Adorno did have very good reasons to be pessimistic.

Instead, emancipatory theory and practice cannot simply be separated without each of them becoming deformed in the process. Marx (1975c, 3) already in the first thesis objects precisely to a philosophy that would conceptualize contemplation as distinct from practice: "[Feuerbach] regards the theoretical attitude as the only genuinely human attitude, while practice is conceived and defined only in its dirty-judaical form of appearance". In Marx's eyes, philosophers were not guilty of interpreting the world, but of merely interpreting it. Mere interpretation is not an excess of interpretation, but quite the opposite: it is an inadequate interpretation of the world in that it fails to grasp how at the same time it is a product of the world it is interpreting and an intervention in it. In short, it fails to grasp its own character as a "practical, humansensuous activity" (Ibid.). ${ }^{2}$ The alternative to mere interpretation is not blind action but what Marx (1843) called "ruthless criticism of all that exists" in a letter to Ruge. Such criticism takes real social struggles as its starting point and intervenes in them, in contrast to those philosophers who Marx chides for acting as if the "stupid, exoteric world had only to open its mouth for the roast pigeons of absolute knowledge to fly into it" (Ibid.).

\section{Praxis, or: On the Unity of Theory and Practice}

Marx did not see philosophy as redundant, but neither was it capable of bringing about social change on its own. In his view, it was not enough to simply think about society in order to truly change it, even if that remained an unavoidable part of political struggles. A parallel line of thought, which can give us a more complex understanding of these issues, was already present in earlier texts of Marx and Engels where they agitated for thinking that would be both a platform for, and based on, practical activity. ${ }^{3}$ Commenting on the French Revolution, they for instance stressed how: "Ideas can never lead beyond an old world order but only beyond the ideas of the old world order. Ideas cannot carry out anything at all. In order to carry out ideas men are needed who can exert practical force" (Marx and Engels 1975b, 119).

This was, again, not to say that ideas as such are not crucial aspects of social struggles. It is precisely political action that has to exert and anchor ideas in social relations. In his Contribution to Critique of Hegel's Philosophy of Law, Marx (1975a, $182,187)$, for example, almost poetically emphasized a similar point when writing:

\footnotetext{
${ }^{2}$ Marx's dialectical approach was also a critique of Feuerbach in the way it aimed to overcome and supersede dualisms that were ever-present in both Feuerbach's writings and the work of his contemporaries. The goal was not only to overcome the theory and practice dualism, but also the deadlock between Hegelian idealism, which Marx credited with developing the activity of the subject, but in an abstract way, and old (Feuerbach's) materialism, with an aim of a new materialism of practice (see Balibar 1995, 15, 17).

${ }^{3}$ It was already in his doctoral dissertation on ancient Greek philosophy that Marx was interested in praxis and "insisted that philosophy be made practical" (Mosco 2009, 35).
} 
The weapon of criticism cannot, of course, replace criticism by weapons, material force must be overthrown by material force; but theory also becomes a material force as soon as it has gripped the masses. Theory is capable of gripping the masses as soon as it becomes radical. /../ As philosophy finds its material weapons in the proletariat, so the proletariat finds its spiritual weapons in philosophy. l../ The head of this emancipation [of the human being] is philosophy, its heart is the proletariat. Philosophy cannot be made a reality without the abolition of the proletariat, the proletariat cannot be abolished without philosophy being made a reality.

As noted by Bloch (1995, 271-272), theory and practice in this sense "continually oscillate. Since both alternately and reciprocally swing into one another, practice presupposes theory, just as it itself further releases and needs new theory in order to continue a new practice". It thus seems obvious that, for Marx, philosophy and theory were far from unimportant. The question in fact was how to realize them, how to enable them to make transformative practice possible. The reasons, according to Marx, seemed obvious: radical analysis or theoretical demystification does not in itself also lead to changes in wider social relations and neither do such theoretical interventions necessarily put an end to the practical reproduction of myths in people's everyday lives. What is needed is political activity that feeds itself on theory. In this regard, praxis is necessarily connected to the socialization of critical thought which, as Gramsci (1971, 323-349) would say, must in effect become a collective activity influencing and transforming social relations and thus becoming a social fact. For Gramsci (Ibid.), the actual influence of philosophy, which is always part and parcel of human existence (knowingly or not), can therefore only be measured through the feedback it made on society.

This "fundamental unity of thinking and doing" (Mosco 2009, 4) characteristic of praxis has been a mainstay of most critical approaches throughout history, including of political economy. As noted by Mosco (Ibid.), this approach has "consistently viewed intellectual life as a means of bringing about social change and social intervention as a means of advancing knowledge". Overturning the artificial gap between research and action (Ibid.) has also been a fundamental goal of critical media and communication studies, especially for the political economy of communication.

As the interviewees' scholarly research and practice largely overlaps with the political economy of communication's approach, it is no surprise that all of the interviews presented in this special section - which, following Marx, we entitled The Point Is to Change It! Critical Political Interventions in Media and Communication Studies in one or another way deal with conscious bridging of the mentioned division. Topics covered in our interviews range from holistic academic interventions and critiques of the increasingly commodified and instrumentalized research and education systems that are structurally making critical scholarship impossible, to policy proposals aimed at restructuring the existing media systems and wider political actions for a more just global communication system that emerged within critical scholarly circles, but later achieved international political resonance.

\section{Legitimation Crisis and the Return of Critical Approaches in Media and Communication}

We live in a historical period of destabilizing economic and political processes in many (Western) countries. These deep social perturbations, as Wallerstein would call 
them, have manifested themselves in the rise of far-right populist nationalistic parties (Mudde 2007), the Brexit vote and the election of Trump as president of the USA, the 'hollowing out' of institutional politics that is losing support and seeing high electoral volatility (Mair 2013), deepening economic divides and inequalities between and within nation states (Beck 2013; Streeck 2013), the looming disintegration of the European monetary union, the absence of a common European public sphere (Trenz $2008,2)$, and the growing concerns over the European democratic project voiced by citizens and academics alike (Habermas 2009).

Contradictory as it might sound, the end of "the end of history" (Mosco 2004, 171174) has therefore proven to be quite a lively and eventful period. Liberal democracy or, to be more precise and borrow a phrase from Wolfgang Streeck $(2013 ; 2014)$, "democratic capitalism" is buckling under the contradictions between its two constituent elements: capitalism and democracy. States are burdened by the debt they have taken on themselves to rescue capitalism from collapse in the wake of the 2007-2008 financial crisis and are left vulnerable to the blackmailing of the international financial markets (lbid.) - the same international financial markets that were the recipients of generous state aid. Austerity has turned out not to be a temporary adjustment to an economic downturn, but has become a permanent structural feature of the contemporary "consolidation state" (Streeck 2015), thereby intensifying pressures for privatization and to make cuts in public services. The balance of power between the two constituents of modern states, markets and people, has swung decisively towards the former. The development of information and communication technologies has been at the heart of these processes as it has been supporting financialization and the spread of global capitalism (Hamelink 1983; Schiller 1999; 2014), intensified processes of commodification (Amon Prodnik 2016), contributed to the standardization and deskilling of intellectual labour (Brown, Lauder and Ashton 2011), and expanded the capacities of states as well as private corporations for widespread surveillance beyond previously imaginable levels (Greenwald 2014).

In the wake of the crisis, capitalism has become unable to return to the levels of growth that would enable it to secure popular consent through concessions in the form of wage growth and wealth redistribution. Instead, reliance on the brute force of international financial markets and unelected technocrats to quell popular resistance is increasing, contributing to a systemic crisis of legitimacy. It has become obvious that, to paraphrase Dorfman and Mattelart $(1971 / 1991,30)$, the velvet glove of the emperor has in fact been concealing an iron fist.

At the same time, mainstream social science - and economics as arguably its most mainstream and simultaneously most prestigious part - has been unable to provide answers to these challenges. One reason for this is the fact that universities have long since become thoroughly integrated into the capitalist system and been heavily influenced by the trend of marketization, especially in the USA (Newfield 2003; Newfield 2008; Slaughter and Rhoades 2004). The dominance of administrative and ahistorical approaches has nearly guaranteed that, as a whole, the social sciences remain blind to the fundamental contradictions of the existing social order, while also being unable to imagine a better world. It is therefore imperative to investigate our collective capacity to formulate critical thought. In the interview, Peter Golding mentions the need to investigate and critically reflect on the funding of media research since he suspects "that in many countries, including international, research funding, for the example by the EU, of critical and theoretically informed political economy research is becoming less and less supported, with administrative, applied 
and uncritical research becoming more common, including industrial and pragmatic 'administrative' research".

Nonetheless, there has been notable growth in research dealing with the problems of labour in media and journalism industries, the commodification of privacy and mass surveillance and the free labour provided by audiences to corporations on digital platforms. Historians have rarely observed news organizations through the lens of labour and focused on the labour process and worker-management conflicts over working conditions, the distribution of power, and wages (cf. Hardt and Brennen 1995; Hardt 1996). Yet, with the global economic crisis exacerbating the longstanding trends of pauperization of newswork, and with newsworkers in the developed world facing mass layoffs, lower wages and worsening working conditions, these issues have been receiving increasing attention. Researchers have been focusing on issues like employment types, wages, job security, management control and workplace conflicts (see, for example, Deuze 2007; Cohen 2015; Mosco and McKercher 2009; Paulussen 2012; Ryan 2009). While this research has helped fill an important gap in communication research, many aspects of newswork remain underresearched. For example, there is a noticeable tendency to focus on professional elites - journalists and editors - while there are far fewer studies looking at other newsworkers like newspaper deliverers (Bekken 1995) and workers who are even lower down on the global commodity chain of contemporary communication and information production (see Fuchs 2016).

Another area of research that has gained traction in recent years is connected to the spread of digital communication technologies and their impact on traditional business models and issues of privacy. First and foremost among the pioneers are Google (or Alphabet, as the corporation is officially called since its 2015 reorganization) and Facebook, which manage to capture an ever larger share of the advertising pie each year by monetising the unpaid work of their users and the massive amounts of user data they are able to capture. The impact of digital technologies has been a subject of scholarly attention from the perspectives of Marx's value theory (Fuchs 2014), commodification and monetization of audiences (Buzzard 2012; Napoli 2011), shifting barriers between content providers, platforms and advertisers, as well as the threat to privacy entailed by the gathering of private data on such massive scales (which Mosco [2014, 137-155] calls capitalist surveillance).

But while it is fair to say there has indeed been renewed interest in a critical politico-economic analysis of communication, these approaches represent a fraction of media and communication studies, a field that has seen (perhaps the most) rapid growth in recent decades. Critical and radical approaches, furthermore, remain increasingly marginalized within this and other fields. As noted by McChesney (2004, 47-48), this cannot really come as a surprise. Critical scholarship, by definition, puts dominant interests under question and challenges their legitimacy. Such a stance by itself makes its financing unattractive to both the state and industry. As Splichal (2014) claimed:

Professional institutionalization of social sciences increased interest in the reliability and validity of applied research but also often tended to over-emphasize the importance of operational definitions and empirical reliability of concepts to solve practical problems - while discriminating against the critical role of theory in steering social development. In some cases, high costs of experimental and field work led professional research into dependence on the policy world and 
capital. Financial support from corporate foundations required researchers to shed and avoid political radicalism (rather than any political alignment).

This means there are deep structural reasons for critical scholarship's marginalization that are often difficult to overcome, an issue also raised by Peter Golding in the interview. Even though funding for critical research has always been scarce, he points out it is shrinking even further.

We therefore live in a context of a dire need for more critical scholarship able to make sense of the vast inequalities and deep legitimation crises that the key social institutions are facing today. The systemic possibilities for such work, however, are being reduced rapidly with the logic of the market not only influencing but fully colonizing and submerging higher education and research for its particular goals to the point that indeed no alternatives remain. The consequences of these processes are not trivial. As Golding so lucidly emphasizes, there is a constant need to provide a critique of all ideological production within societies, but - and one cannot overemphasize this point - "if universities are not places where radical critique is possible and allowed to be articulated and injected into public debate, then where is?".

\section{The Many Faces of Globalization}

A historical perspective is crucial for critical scholarship not only for understanding long-lasting historical trends, but also to remind ourselves that the world is malleable, and to keep alive the promises of the progressive struggles of the past. In the absence of a historical perspective, the status quo can seem to be set in stone, while contemporary trends can appear transhistorical and preordained rather than contingent. One such instance is the dominance of the market-based, neoliberal model of globalization, which has become synonymous with globalization itself. Opposition to neoliberal globalization is often denounced as anti-globalism, as a naïve and utopian attempt to halt the inevitable march of progress. What such a perspective overlooks is that the neoliberal model's dominance was only enabled after the alternative visions of globalization, very much alive and influential in the 1970s and 1980s, were crushed and exiled from international institutions like the UN and UNESCO. As Breda Pavlič notes in the interview regarding the leading capitalist powers' fierce reaction to UNESCO's attempts to promote a New World Information and Communication Order (NWICO):

With hindsight one understands even better the stakes on both sides. In a nutshell I would say that the assault on UNESCO and the MacBride Report was basically spurred by big-capital interests. The media and all of information \& communication being an essential instrument of economic, financial and political power, the global corporations and big-capital in general could not tolerate anyone's interference in this area. When the Non-Aligned Countries and the Group of 77 began organizing itself in this regard (the Pool, and various SouthSouth networks of cooperation that followed) and, moreover, succeeded in influencing the UN and its agencies (UNESCO) to move in that direction, the corporate-big-capital powers clearly became sufficiently alarmed to stifle the process.

The move against UNESCO was masked by an apparent concern for freedom of the press (Roach 1987, 38) and the US authorities quoted UNESCO's supposed endemic hostility "towards a free press, free markets and individual human rights" 
(Ayres 1984) when leaving the organization in protest in 1984. In truth, the move was part of a broader attack not just on the Non-Aligned Movement and developing countries, but against the United Nations and the principle of multilateralism in international relations. As Osolnik claims in the interview: "They [the USA and the UK] wanted to show the Non-Aligned countries, which already had the majority in these global organisations, that they could not play around with this majority. The first measure against UNESCO was in fact only the beginning of a sharp international course the Americans then chose". Hamelink drew a similar conclusion about the naïve belief of decolonized states that the 'One state - one vote' principle could in fact provide a different form of governance for the world economy.

It is therefore crucial to take a historical view at globalization processes not simply to understand their development, but in addition to understand and keep alive more progressive alternatives. The countries that today act as driving forces and chief promoters of globalization were acting as chief opponents of these alternative visions of globalization in the 1970s and 1980s. As Bockman $(2015,109)$ argues:

If we examine economic globalization more closely and from the perspective of Second and Third World institutions, we can see that the Non-Aligned Movement, the Second World, and the Third World more broadly worked hard to create a global economy in the face of active resistance by the United States and other current and former colonial powers, which sought to maintain the economic status quo of the colonial system.

The vision for an alternative global economy was strongly based on the experience of former colonies that gained independence after the end of World War II. It became clear to them that relationships of substantive inequality and dependence were persisting notwithstanding their formal independence. Global development remained unequal and, despite some efforts on the part of the United Nations (UN) and the United Nations Commission on Trade and Development (UNCTAD), the gap between developed and developing countries was not shrinking (Sauvant 1977, 4). This persisting gap was being challenged by developing countries, most strongly by the Non-Aligned Movement, as a symptom of the structural deficiencies of the world economic system that has failed to break with its colonial past. In this sense, leaders of the Non-Aligned Movement saw the contemporary economic system as a continuation of colonialism by other means and claimed that the: "persistence of an inequitable world economic system inherited from the colonial past and continued through present neo-colonialism poses insurmountable difficulties in breaking the bondage of poverty and shackles of economic dependence" (Resolutions 1970, 21).

While developing countries were occupying a subordinate position in the world economic system, they were by no means powerless. Several factors enabled them to organize and use the forum of the UN to adopt favourable resolutions regarding their demands for a fundamental restructuring of global economic relations to the benefit of equality and development. Post-war economic growth was heavily dependent on natural resources controlled by developing countries - particularly oil - and through organized action and willingness to assert sovereignty over resources within their borders (cf. Documents 1973, 67) they were able to use this to their advantage. As the international activity of (primarily US) corporations was increasing (Gwin 1977, 89; Sauvant 1977, 8), access to the markets and resources of developing countries, which could not be gained through coercion alone, was in the interest of the developed countries. Finally, the relative stalemate of the blocs in the Cold War meant that 
through the politics of non-alignment and cooperation in the forum of the UN (particularly via the Group of 77) developing countries could be very successful in asserting their interests.

The strengthening of trade was very much on the agenda of developing countries, both in the sense of demands for developed countries to remove trade barriers and positive measures to strengthen the developing countries' position in global trade as well as cooperation among themselves (so-called South-South cooperation), while the US tended to see these attempts as a threat to its hegemony and was particularly opposed to engaging in free trade with communist countries (Bockman 2015, 112). The aim of the New International Economic Order (NIEO) was to achieve developing countries' more equitable position in world trade and the global division of labour and it thereby demanded concessions and adjustment from developed countries. It was clearly not a revolutionary programme, but it nonetheless envisioned far-reaching alterations to the global economic system, "changing its mechanisms and structures to serve new aims" (Sauvant 1977, 10), that is, to achieve more equal development and to strengthen the position of developing countries.

\section{A New World Information and Communication Order: The Alternative Path for International Communication and its Antagonists}

Discussions on the NIEO were an important basis for the demands for a New World Information and Communication Order (NWICO). They opened and articulated questions of global inequalities and imbalances between the developed North and developing South. In this context, some studies found that information and communication flows are also highly unbalanced, with content predominantly flowing from the developed to the developing countries (Nordenstreng and Varis 1974). Critical media and communication scholars connected these imbalances to questions of cultural and media imperialism (Boyd-Barrett 1977; 1982; Schiller 2000), the ideological influence exerted by imported cultural goods as well as the reproduction of inequalities within the international trade of different types of commodities (Dorfman and Mattelart 1971/1991). ${ }^{4}$ These imbalances constructed new dependencies that were intellectually reflected through the frameworks of cultural imperialism and dependency theory.

At the same time, the ways of addressing these problems were also similar between the two initiatives as developing countries found that the UN forum with - at least in principle - equal representation of all nations enabled them to exert an influence that far surpassed their economic and military clout. Therefore, UNESCO be-

\footnotetext{
${ }^{4}$ As written by Dorfman and Mattelart (1971/1991, 97-98), the dependent country is dependent on the capitalist centre "precisely because it depends on commodities arising economically and intellectually in the power center's totally alien (foreign) conditions. Our countries are exporters of raw materials, and importers of super-structural and cultural goods. To service our 'monoproduct' economies and provide urban paraphernalia, we send copper, and they send machines to extract copper, and, of course, Coca Cola. Behind the Coca Cola stands a whole structure of expectations and models of behavior, and with it, a particular kind of present and future society, and an interpretation of the past. As we import the industrial product conceived, packaged and labelled abroad, and sold to the profit of the rich foreign uncle, at the same time we also import the foreign cultural forms of that society, but without their context: the advanced capitalist social conditions upon which they are based. It is historically proven that the dependent countries have been maintained in dependency by the continued international division of labor which restricts any development capable of leading to economic independence".
} 
came a crucial arena for debates on the NWICO as UNCTAD was for debates on the NIEO.

As with the NIEO, the NWICO's goal was not to limit global information and communication flows but to strengthen the position of the weakest countries, increasing their output of cultural goods to the developed world in order to improve inter-cultural understanding and enhance the developing world's independence by increasing South-South cooperation, for example through news-exchange mechanisms like the Non-Aligned News Agencies Pool (NANAP) and other forms of news cooperation schemes (for an overview, see Jakubowicz 1985). But the NWICO was not merely the NIEO applied to information and communication. The most innovative proposals of the MacBride Commission were those pertaining to the democratization of communication (Thussu 2005, 33-34), to constructing two-way communication systems that enable not only access but also participation and exchange.

Faced with the Scylla of free market fundamentalism and the Charybdis of Soviet etatism, the Commission managed to steer clear of both monsters by developing the notion of the right to communicate as an individual human right. In this conception, the right to communicate is not merely a formal right but demands that means be made available in order that people may take an active role in communication processes. In this sense, the right to communicate can be violated not simply by state censorship, but also by corporate monopolies and underdeveloped infrastructure, as well as the subjugation of the freedom of expression to the freedom of the entrepreneur. The Report made it quite clear that the Commission regards communication first and foremost as a fundamental human right and a social need: "The freedom of a citizen or social group to have access to communication, both as recipients and contributors, cannot be compared to the freedom of an investor to derive profit from the media. One protects a fundamental human right, the other permits the commercialization of a social need" (UNESCO 1980, 18).

This alternative vision conflicted strongly with powerful interests. Private corporations in the developed world had a keen interest in penetrating developing countries and had little intent to tolerate the attempts to develop indigenous capacities in the developing world. Attempts to strengthen the developing countries' position through the news exchange mechanisms came into stark conflict with the interests of the big four international news agencies (AP, Reuters, AFP and UPI) in global market dominance (Sauvio 2012, 236). Further, the US government regarded the cultural sphere as a crucial battleground for securing global hegemony, as evidenced by the CIA's extensive involvement in the field (Stonor Saunders 1999).

It is therefore not surprising that Western media greeted the NWICO initiative less than enthusiastically. As McChesney $(2008,351)$ claims, "the U.S. press regarded [NWICO] as a distinct threat to its modus operandi overseas. The press coverage was totally one-sided. /../ [It] characterized the NWICO as a callous effort by secondrate hacks to manipulate the news and interfere with a free press". The 1980 UNESCO general conference in Belgrade, where the MacBride Commission recommendations were adopted by consensus, was covered overwhelmingly negatively in the French Press, which reported on UNESCO's alleged support for government control of the press and omitted reporting rebuttals of such claims by UNESCO's director-general (Roach 1981). US news media coverage was so strongly one-sided and hostile to the degree that only a small minority of news sources even attempted to explain the position of the other side (Raskin 1981).

Yet, notwithstanding the obvious bias in these reports and the conflict of interest of the leading global news media and news agencies reporting on a proposal that might 
threaten their profits, the critiques were not groundless. Supposed friends of the NWICO initiative were at the same time its liability. Allegations by capitalist powers that the initiative was being (mis)used to distract from infringements of the freedom of expression in developing countries held true in many cases (cf. Mattelart 2011, 503504). Daya Thussu notes a telling paradox in the interview:

Indira Gandhi was the prime minister of India and she had imposed a state of emergency which involved muzzling the press. Thankfully, it was only for two years: 1975 to 1977 . During this period, she was going around the world and telling Western media that you guys distort reality, you do this, you do that ... but at home she had journalists arrested and newspapers were shut.

The Soviet bloc also opportunistically backed the NWICO efforts because it was hoping to "impose wider circulation of its material" (Sauvio 2012, 235), a move that further increased the West's animosity towards the initiative. Finally, the election of Margaret Thatcher in the UK and Ronald Reagan in the USA meant that radicals were now in power who were prepared to take drastic steps in order to secure Western hegemony and put the developing world in its place. The attack on UNESCO was part of a broader neoliberal turn in international relations and the withdrawal of the USA from UNESCO in 1984, followed by the UK and Singapore in 1985, effectively put a stop to the NWICO initiative.

\section{The Political Economy of Communication in its Watershed Period}

This same period of the 1970s and 1980s was a watershed era for critical media and communication studies, especially for the political economy of communication. After the approach's very conflictual formal emergence in the 1950s and 1960s, when Dallas Smythe, Herbert I. Schiller and Thomas Guback published the first works that explicitly debated the political economy of communication, while also enduring considerable political pressures (see Smythe 1994; Schiller 2000; Maxwell 2003), the final years of the 1960s and 1970s enabled an expansion of critical approaches. Earlier non-administrative authors in the USA were entrapped in the Cold War context and the McCarthyist witch-hunt, with vast peer-pressures in academia and any serious critique of the system even potentially leading to the loss of a job. As noted by Schiller $(2000,21)$, the political atmosphere after Harry Truman's election win in 1948 "was overhung by the reality of investigations commissions, firings, the blacklist, and the generalised repression and coercion", with oppositional voices silenced: "A curtain had come down in America, smothering free discussion" (Ibid. 22).

Only later, with geo-political perturbations (especially several years of decolonization and Vietnam War protests) and new social movements coupled with counterculture, could critical voices re-emerge in earnest. Several authors, including Schiller (2000, 118-120), Meehan and Wasko (2013), McChesney $(1998,11)$ and Nordenstreng $(2004,6-8)$ thus agree that the late 1960s and 1970 s were in many respects the most open for critical approaches in media and communication studies and the era of their strongest expansion. This includes the political economy of communication, which experienced a phase of considerable intellectual strengthening, while "for about a decade, the hegemony of establishment communication theory and scholarship was on the defensive" (Schiller 2000, 119).

Even though the NWICO initiative and recommendations made in the MacBride Commission Report failed to provide fundamental transformations in world communication, there remains a consensus in critical literature that this was perhaps the most 
important critical political initiative in media and communication, especially since it was closely connected to the academic community. The MacBride Report was a culmination of the NWICO because it took into consideration all of the working papers (approx. 100) that had been prepared within UNESCO's programme, which attempted to analyse what were the relations between the new international economic order and the new communication order (Thussu 2005, 50). Following publication of the MacBride Report, one such report entitled The New International Economic Order: Links between Economics and Communications was prepared by Breda Pavlič and Cees Hamelink (1985), who we both interviewed for this thematic section. In the paper, they analysed the dialectical relation between "economic" and "non-economic" that are often artificially separated, even though the mass media and ICTs "have long since developed into industrial and business activities and are linked to a society's economics in more than one way" (Ibid., 10). What is perhaps especially important in today's context of vast global conglomerates is their pertinent observation linked to technological convergence:

The convergent nature of information-communication technology also implies strong industrial concentration. Formerly separate fields such as data processing, text processing, information storage, photocopying, and information transmission are increasingly integrated through the merger of technologies and can be operated by a single, vertically integrated corporation. /.../ One of the basic assertions of this study is that developments of technology such as digitalization of information require that mass communications and computer communications (including telecommunications) be no longer treated as separate issues. Media-data convergence, as this process is called, lies at the heart of the present technological revolution in the information-communication area, and is crucial to understanding the relationship between economic and communications process. (Ibid., 10-11)

Their observation proved to be correct, with one of the key trends in the last decades being "the growth of large media corporations that have exploited new opportunities to establish multiple media ownership nationally and to transcend national boundaries in ownership and operations" (Hardy 2014, 81), also due to "digitalisation and technological convergence [that] have increased the strategic importance of connections between and across businesses formerly organised around distinct market sectors and services" (Ibid. 83).

\section{For a Ruthless Criticism of Everything that Exists}

It is undeniable that many of the issues and antagonisms we are witnessing today have a long history, with their roots firmly based in the 1970s and 1980s. Our interest in this watershed historical era, which is present throughout the interviews, therefore cannot be simply seen as nostalgia. It is an attempt to understand historical relations of power in a period that was by all accounts momentous and has not been repeated on the level of political action or academic articulation of critical ideas in the field of media and communication. Marx and Engels might have gone a step too far when claiming in German Ideology: "We know only a single science, the science of history" (1932/1968). Nonetheless, we firmly hold on to the belief that an in-depth understanding of historical processes and transformations is fundamental to a comprehensive analysis of present social conditions not only for historians, but for the social sciences as a whole (cf. Williams 1961; Braudel 1980, 34; Wallerstein 1998). 
Even though proposals that emanated from the NWICO were ultimately unsuccessful, they thus remain fundamentally important because of their determined and vocal demands for global communication democracy. The NWICO was the first initiative that demanded "universal access to communication media, control over decisions about the production and distribution of communication, and the basic human right to communicate" (Mosco 2009, 72) on such a large scale. It also "gave a political purpose to a dynamic new research agenda for political economy of communication" (Ibid.), which may be seen as a direct connection between theory and practice, and opened the doors for radical research approaches in this field. Thussu (2015, 252) saw the MacBride Report, which was a direct consequence of the NWICO, as "arguably one of the most significant multilateral interventions in the history of international communication".

Accordingly, it remains vital to critically evaluate the NWICO's ideas and their relevance to the present era. It is important to keep these critical approaches and alternative visions of globalization alive, especially since they have been thoroughly purged from the collective and institutional memory. As Breda Pavlič notes in the interview regarding UNESCO and NWICO: "Today, it seems as if it never existed! It has been deleted not only from subsequent and present programme and budget, but largely also from its institutional memory". "While the NWICO was a product of its time - both of the intellectual atmosphere as well as of the political space that opened up between the two opposing blocs to make non-alignment an effective political position - and cannot be merely transplanted to the present, the guiding principles remain the same for contemporary critical scholarship and emancipatory political practice as they were 40 years ago. To quote the MacBride Report, our task must be to ensure that the "media of 'information' become the media of 'communication"” (UNESCO 1980, 212). In this respect, the proposal to democratise journalism by making the public directly involved in the distribution of public subsidies that Dan Hind is advocating and which is the primary focus of the interview, can be seen as a contemporary application of the principles espoused by the MacBride Commission. Hind points out that editors and journalists act not only as a check on governmental power, but they themselves wield considerable power that is often obscured:

As you know at the current time we have a kind of coalition of professional and owner groups who determine the news agenda in an essentially invisible process. It is secluded from public scrutiny and it stands in very marked contrast to the journalistic instinct to make everything public. The means by which they make things public are kept substantially obscure.

Democratization of the means of (mass) communication remains an important goal for any emancipatory struggle not only because participation in the life of the community through communication is a fundamental social need and a valuable goal in and of itself. To return to the relationship between understanding the world and changing it discussed at the start of this article, the media of communication have

\footnotetext{
${ }^{5}$ It is telling that according to the official website of UNESCO (2016), the USA withdrew because of "disagreement over management and other issues". In contrast, the reasons for the withdrawal of the Republic of South Africa in 1956 are clearly stated as supposed interference with the country's "racial problems". One can imagine a top-secret communique informing all UNESCO employees that the NWICO must from now on be referred to strictly as 'other issues', while Sean Macbride should be referred to only as 'He who must not be named'.
} 
come to play such an integral role in the way people understand the world that meaningful progressive social change is hard to imagine unless our tools for understanding the world are reformed. As Hind puts it in the interview:

I can't imagine a radically reformed political economy that isn't built on a radically reformed public sphere, that isn't built on a radically different set of generally accepted descriptions. It seems to me that it is prior to any kind of hope we might have for a reasonably orderly transition to an economy that is reasonably just, reasonably sustainable and not as obviously pathological as the one we have now.

Robert McChesney, who has also been advocating for media reform in the US context, similarly views the essence of the battle over media and communication to be "about whether people or corporations, public interest or private profit, should rule the realm of communication" (McChesney 2008, 499). Movements for the reform of the media system and communication order will therefore at some point have to go into "direct confrontation with capital" (Ibid.). According to McChesney, the question of media reform is not secondary to broader social reforms since "no one thinks any longer that media reform is an issue to solve 'after the revolution'. Everyone understands that without media reform, there will be no revolution" (Ibid.).

If a young Marx believed that "criticism of religion is the prerequisite of all criticism" (Marx 1844/2009), nowadays that wording would have to be broadened to include both the media and the conditions of "intellectual production whether it's at universities or anywhere else", as Golding claims in the interview. We hope that the interviews presented in this section can contribute at least a little to this goal.

\section{References}

Adorno, Theodor W. 1966/1973. Negative Dialectics. London and New York: Routledge.

Amon Prodnik, Jernej. 2016. 3C: Commodifying Communication in Capitalism. In Marx in the age of digital capitalism, edited by Christian Fuchs and Vincent Mosco, 233-321. Leiden and Boston: Brill.

Ayres, Drummond B. 1984. U.S. Affirms Plan to Leave UNESCO at End of Month. New York Times, December 30. Accessed February 12, 2017.

http://www.nytimes.com/1984/12/20/us/us-affirms-plan-to-leave-unesco-at-end-ofmonth.html

Balibar, Etienne. 1995. The Philosophy of Marx. London and New York: Verso.

Beck, Ulrich. 2013. German Europe. Cambridge: Polity.

Bekken, Jon. 1995. Newsboys. In Newsworkers, edited by Hanno Hardt and Bonnie Brennen, 190-226. Minneapolis: University of Minnesota Press.

Bloch, Ernst. 1995. The Principle of Hope (Volume One). Cambridge, Massachusetts: MIT Press.

Bockman, Johanna. 2015. Socialist Globalization against Capitalist Neocolonialism: The Economic Ideas behind the New International Economic Order. In Humanity: An International Journal of Human Rights, Humanitarianism, and Development 6 (1): 109-128.

Boyd-Barrett, Oliver. 1977. Media Imperialism: Towards an International Framework for the Analysis of the Media Systems. In Mass Communication and Society, edited by James Curran, Michael Gurevitch and Janet Woollacott, 116-135. London: Edward Arnold.

Boyd-Barrett, Oliver. 1982. Western News Agencies and the "Media Imperialism" Debate: What Kind of Data-Base? Journal of International Affairs 35 (2): 247-260.

Braudel, Fernand. 1980. On History. Chicago: University of Chicago Press. 
Brown, Phillip, Hugh Lauder, and David Ashton. 2011. The Global Auction: the Broken Promises of Education, Jobs, and Incomes. Oxford and New York: Oxford University Press.

Buzzard, Karen. 2012. Tracking the Audience. London and New York: Routledge.

Cohen, Nicole. 2015. From Pink Slips to Pink Slime. The Communication Review 18 (2): 98122.

Deuze, Mark. 2008. The Changing Context of Newswork. International Journal of Communication 2 (5): 848-865.

Documents of the Fourth Conference of Heads of State or Government of Non-Aligned Countries. 1973. Accessed February 6, 2017.

http://cns.miis.edu/nam/documents/Official Document/4th Summit FD Algiers Declarati on 1973 Whole.pdf

Dorfman, Ariel and Armand Mattelart. 1971/1991. How to Read Donald Duck? Imperialist Ideology in the Disney Comic. New York: International General.

Fuchs, Christian. 2014. Digital labour and Karl Marx. London and New York: Routledge.

Fuchs, Christian. 2016. Digital Labor and Imperialism. Monthly Review (67) 8. Accessed February 2, 2017. https://monthlyreview.org/2016/01/01/digital-labor-and-imperialism/

Gramsci, Antonio. 1971. Selections from the Prison Notebooks. London: Lawrence \& Wishart.

Greenwald, Glen. 2014. No Place to Hide: Edward Snowden, the NSA, and the U.S. Surveillance State. New York: Metropolitan Books.

Habermas, Jürgen. 2009. Europe, the Faltering Project. Cambridge: Polity.

Hamelink, Cees. 1983. Finance and Information: A Study of Converging Interests. Norwood, New Jersey: Ablex Publishing Corporation.

Hardt, Hanno and Bonnie Brennen. 1995. Introduction. In Newsworkers, edited by Hanno Hardt and Bonnie Brennen, vii-xiii. Minneapolis and London: University of Minnesota Press.

Hardt, Hanno. 1996. The End of Journalism. Javnost - The Public 3 (3): 21-42.

Hardy, Jonathan. 2014. Critical Political Economy of the Media. London and New York: Routledge.

Jakubowicz, Karol. 1985. Third World News Cooperation Schemes in Building a New International Communication Order: Do They Stand a Chance? Gazette 36: 81-93.

Mair, Peter. 2013. Ruling the Void: The Hollowing of Western Democracy. London: Verso.

Marx, Karl. 1844/2009. A Contribution to the Critique of Hegel's Philosophy of Right, Introduction. Accessed February 7, 2017. https://www.marxists.org/archive/marx/works/1843/critique-hpr/intro.htm

Marx, Karl and Friederich Engels. 1932/1968. The German Ideology, Part I: Feuerbach, A. Idealism and Materialism. Accessed February 7, 2017. https://www.marxists.org/archive/marx/works/1845/german-ideology/ch01a.htm

Marx, Karl. 1843. Marx to Ruge. Accessed March 5, 2017. https://www.marxists.org/archive/marx/works/1843/letters/43 09.htm

Marx, Karl and Frederick Engels. 1975a. Collected Works, Volume 3 (1843-1844). London: Lawrence \& Wishart.

Marx, Karl and Frederick Engels. 1975b. Collected Works, Volume 4 (1844-1845). London: Lawrence \& Wishart.

Marx, Karl and Frederick Engels. 1975c. Collected Works, Volume 5 (1845-1847). London: Lawrence \& Wishart.

Maxwell, Richard. 2003. Herbert Schiller. Lanham: Rowman and Littlefield.

Mattelart, Armand. 2011. New International Debates on Culture, Information, and Communication. In The Handbook of Political Economy of Communications, edited by Janet Wasko, Graham Murdock and Helena Sousa, 501-520. Malden and Oxford: WileyBlackwell.

McChesney, Robert Waterman. 1998. The Political Economy of Global Communication. In Capitalism and the Information Age: The Political Economy of the Global Communication 
Revolution, edited by Robert W. McChesney, Ellen Meiksins Wood and John Bellamy Foster, 1-26. New York: Monthly Review Press.

McChesney, Robert Waterman. 2004. Making a Molehill out of a Mountain: The Sad State of Political Economy in U. S. Media Studies. In Toward a Political Economy of Culture: Capitalism and Communication in the Twenty-First Century, edited by Andrew Calabrese and Colin Sparks, 41-64. Lanham, New York, and Oxford: Rowman \& Littlefield Publishers.

McChesney, Robert Waterman. 2008. The Political Economy of Media: Enduring Issues, Emerging Dilemmas. New York: Monthly Review Press.

Meehan, Eileen R. and Janet Wasko. 2013. In Defense of a Political Economy of the Media. Javnost - The Public 1 (20): 39-54.

Mosco, Vincent. 2004. The Digital Sublime: Myth, Power, and Cyberspace. Cambridge and London: The MIT Press.

Mosco, Vincent. 2009. The Political Economy of Communication. Second Edition. Los Angeles and London: Sage.

Mosco, Vincent. 2014. To the Cloud: Big Data in a Turbulent World. Boulder: Paradigm

Mosco, Vincent and Catherine McKercher. 2009. Convergence Bites Back. Canadian Journal of Communication 31 (3): 733-751.

Mudde, Cas. 2007. Populist radical right parties in Europe. Cambridge: Cambridge University Press.

Napoli Phillip M. 2011. Audience Evolution: New Technologies and the Transformation of Media Audiences. New York: Columbia University Press.

Newfield, Christopher. 2003. Ivy and Industry: Business and the Making of the American University, 1880-1980. Durham and London: Duke University Press.

Newfield, Christopher. 2008. Unmaking the Public University: The Forty-Year Assault on the Middle Class. Cambridge, Massachussets and London: Harvard University Press.

Nordenstreng, Kaarle. 2004. Ferment in the Field: Notes on the Evolution of Communication Studies and Its Disciplinary Nature. Javnost - The Public 11 (3): 5-18.

Nordenstreng, Kaarle and Tapio Varis. 1974. Television Traffic- A One-Way Street? A Survey and Analysis of the International Flow of Television Programme Material. [UNESCO Reports and Papers on Mass Communication, No. 70]. Paris: UNESCO.

Pavlič, Breda and Cees Hamelink. 1985. The New International Economic Order: Links between Economics and Communications. Paris: UNESCO.

Raskin, A. H. 1981. U.S. News Coverage of the Belgrade Unesco Conference. Journal of Communication 31 (4): 164-174.

Resolutions of the Third Conference of Non-Aligned States. 1970. Accessed February 6, 2017.

http://dspace.africaportal.org/jspui/bitstream/123456789/32710/1/SAIIA\%20RESOLUTION S\%20OF\%20THE\%20THIRD\%20CONFERENCE\%20OF\%20NONALIGNED\%20STATES.pdf?1

Roach, Colleen. 1981. French Press Coverage of the Belgrade Unesco Conference. Journal of Communication 31 (4): 175-187.

Roach, Colleen. 1987. The US Position on the New World Information and Communication Order. Journal of Communication 37 (4): 36-51.

Ryan, Kathleen. 2009. The Performative Journalist. Journalism 10 (5): 647-664.

Sauvant, Karl P. 1977. Toward the New International Economic Order. In The New International Economic Order: Confrontation or Cooperation between North and South?, edited by Karl P. Sauvant and Hajo Hasenpflug, 3-19. Boulder: Westview Press.

Sauvio, Robert. 2012. From New International Information Order to New Information Market Order. In From NWICO to WSIS, edited by Divina Frau-Meigs, Jérémie Nicey, Michael Palmer, Julia Pohle and Patricio Tupper, 234-238. Bristol: Intellect.

Schiller, Dan. 1999. Digital Capitalism: Networking the Global Market System. Cambridge and London: MIT Press. 
Schiller, Dan. 2014. Digital Depression: Information Technology and Economic Crisis. Urbana, Chicago and Springfield: University of Illinois Press.

Schiller, Herbert Irving. 2000. Living in the Number One Country: Reflections from a Critic of American Empire. New York, London and Sydney: Seven Stories Press.

Slaughter, Sheila and Gary Rhoades. 2004. Academic Capitalism and the New Economy: Markets, State, and Higher Education. Baltimore: The Johns Hopkins Univeristy Press.

Smythe, Dallas W. 1994. Excerpts from Autobiography, Chapter 5 (1937-1948) and Chapter 4 (1948-1963): The Political Economy of Communications. In Counterclockwise: Perspectives on Communication, edited by Thomas Guback, 13-58. Boulder, San Francisco and Oxford: Westview Press.

Splichal, Slavko. 2014. On (Re)conceptualisations in Communication Research: "Never go Forward Without Going Back First to Check the Direction". Keynote address at the Open Conference of the COST Action IS0906 Transforming Audiences, Transforming Societies: The future of audience research: Agenda, theory and societal significance. University of Ljubljana, Slovenia, February 5 - 7.

Stonor Saunders, Frances. 1999. The Cultural Cold War: The CIA and the World of Arts and Letters. New York and London: The New Press.

Streeck, Wolfgang. 2013. The Crisis in Context: Democratic Capitalism and its Contradictions. In Politics in the Age of Austerity, edited by Armin Schäfer and Wolfgang Streeck, 262-286. London: Verso.

Streeck, Wolfang. 2014. Buying Time. London and New York: Verso.

Streeck, Wolfgang. 2015. The Rise of the European Consolidation State. MPIfG Discussion Paper 15/1. Accessed February 12, 2017. http://www.mpifg.de/pu/mpifg dp/dp15-1.pdf

Thussu, Daya Kishnan. 2005. From MacBride to Murdoch: The Marketisation of Global Communication. Javnost - The Public 12 (3): 47-60.

Thussu, Daya Kishnan. 2015. Reinventing 'Many Voices': MacBride and a Digital New World Information and Communication Order. Javnost - The Public 22 (3): 252-263.

Trenz, Hans-Jörg. 2008. In Search of the European Public Sphere: Between Normative Overstretch and Empirical Disenchantment. Arena Working Paper 12/2008. Accessed February 10, 2017. http://www.sv.uio.no/arena/english/research/publications/arenaworking-papers/2001-2010/2008/wp08 12.html

UNESCO. 1980. Many Voices, One World: Report by the International Commission for the Study of Communication Problems. Accessed January 20, 2016. http://unesdoc.unesco.org/images/0004/000400/040066eb.pdf

UNESCO. 2016. Milestones. Accessed March 6, 2017. http://www.unesco.org/new/en/unesco/about-us/who-we-are/history/milestones/

Wallerstein, Immanuel. 1998. Utopistics: Or, Historical Choices of the Twenty-first Century. New York: The New Press.

Williams, Raymond. 1961. The Long Revolution: An Analysis of the Democratic, Industrial, and Cultural Changes Transforming Our Society. New York: Columbia University Press.

\section{About the Authors}

\section{Sašo Slaček Brlek}

Researcher at the Social Communications Research Centre at the Faculty of Social Sciences of the University of Ljubljana. His main research interests include theories of public opinion and the public sphere, and the critical political economy of communication with a particular focus on researching newswork and newsworkers from the labour process perspective.

\section{Jernej Amon Prodnik}

Assistant Professor at the Department of Journalism, Faculty of Social Sciences, University of Ljubljana (Slovenia), and researcher at the Social Communications Research Centre, 
which is based at the same institution. Between 2014 and 2015, he was a post-doctoral researcher at the Institute of Communication Studies and Journalism at the Faculty of Social Sciences, Charles University in Prague. His principal research interests encompass critique of political economy and historical transformations of capitalist societies with an emphasis on media and communication. 